\title{
Game Simulasi Gerakan Pasien Cedera Bahu Menggunakan Jaringan Saraf Tiruan Backpropagation
}

\author{
KHANIF AZHAR ANAS WALUYO ${ }^{1}$, ESMERALDA C. DJAMAL ${ }^{2}$, REZKI YUNIARTI ${ }^{3}$ \\ 1,2,3 Jurusan Teknik Informatika, Fakultas Sains dan Informatika \\ Universitas Jenderal Achmad Yani \\ Jl. Terusan Sudirman, Cimahi \\ Email : khanifazhaaar@gmail.com ${ }^{1}$
}

\begin{abstract}
ABSTRAK
Bahu merupakan bagian dari lengan yang mudah mengalami cedera. Cedera pada bahu antara lain peradangan sendi, pergeseran tulang (dislokasi), dan bahu kaku (frozen shoulder) serta pasca stroke. Selain itu, penyebab bahu cedera karena olahraga yang menitikberatkan lengan sebagai tumpuan. Latihan terapi yang terjadwal merupakan upaya merehabilitasi bahu untuk memulihkan dan mengembalikan fungsi bahu. Namun kegiatan rehabilitasi medik memerlukan jangka waktu lama dan terkesan monoton yang berakibat menurunnya motivasi pasien dalam menjalani latihan terapi. Sementara itu, perkembangan teknologi yang memudahkan berbagai aspek kehidupan khususnya dibidang kesehatan menjadikan video game dan perangkat sensor Kinect dapat diterapkan sebagai media dalam simulasi latihan terapi cedera bahu. Penelitian ini telah membangun game simulasi sebagai visualisasi untuk mendukung latihan terapi cedera bahu dan kemampuan dalam memprediksi pemulihan cedera bahu pasien yang terbagi atas tiga kelas yaitu "Meningkat", "Tetap", dan "Menurun". Pasien melakukan gerakan untuk mengontrol game dengan mengangkat lengan menjauhi garis tengah terhadap bidang frontal pada tubuh atau disebut sebagai gerakan Shoulder Active Abduction. Gerakan dilakukan oleh salah satu lengan cedera yang akan menghasilkan nilai sudut bervariasi dengan rentang $0^{\circ}$ $180^{\circ}$. Gerakan yang dilakukan direkam sensor Kinect yang dapat memvisualisasikan peta gerakan kerangka tubuh atau disebut matchstick skeleton. Keluaran dari sensor Kinect berupa nilai koordinat yang direpresentasikan ke dalam nilai sudut. Data latih diperoleh dari lima naracoba yang menghasilkan nilai sudut berbeda. Nilai-nilai sudut dilakukan pelatihan menggunakan Backpropagation yang selanjutnya menghasilkan nilai akurasi. Hasil pelatihan dengan learning rate 0,01 menunjukan akurasi sebesar 82\% untuk prediksi data yang sudah dilatih, sedangkan pengujian data baru menunjukan akuarasi sebesar 66,7\%.
\end{abstract}

Kata kunci; cedera bahu; frozen shoulder; rehabilitasi; shoulder active abduction; game simulasi; backpropagation; real time.

\section{PENDAHULUAN}

Gangguan pada bahu diantaranya peradangan sendi, pergeseran tulang (dislokasi), dan bahu kaku (Frozen shoulder), pasca stroke serta olahraga dimana lengan sebagai tumpuan. Frozen Shoulder merupakan gangguan bahu yang cukup serius karena memiliki tingkatan cedera yang bervariasi mulai dari gerakan bahu yang sangat terbatas hingga tidak dapat digerakan sama sekali [1]. Diperlukan tindakan untuk memulihkan dan mengembalikan fungsi bahu seperti semula dengan melakukan serangkaian proses rehabilitasi medik. Rehabilitasi medik mengandalkan terapi fisik tanpa harus mengkonsumsi obat yang bertujuan mengembalikan fungsi fisik, emosi kognisi, dan sosial pada individu untuk meningkatkan kualitas hidup [2]. 
Tetapi rehabilitasi medik relatif membutuhkan waktu lama dengan melakukan kegiatan yang sama. Hal tersebut terkesan monoton yang dapat berpengaruh pada motivasi dan semangat pasien sehingga proses pemulihan tidak akan maksimal. Pemulihan cedera tergantung dari seberapa rutin latihan terapi dan pencapaian target yang dilakukan. Terapi latihan tidak harus berkunjung pada fisioterapis, namun dapat dilakukan mandiri tetapi tetap dipantau [3]. Dalam kasus cedera bahu Frozen shoulder, gerakan latihan terapi dapat berupa gerakan Shoulder Active Abduction dimana lengan diangkat menjauhi garis tengah terhadap bidang frontal pada tubuh.

Teknologi yang berinovasi menjadikan video game dapat digunakan sebagai simulasi untuk mendukung proses rehabilitasi medik [4], beserta dengan sensor gerak 3D yaitu Kinect [5]. Simulasi yaitu menggambarkan suatu kejadian atau bagian dari peristiwa yang ada pada dunia nyata. Pada kasus ini yang menjadi fokus utama yaitu gerakan Shoulder Active Abduction yang disimulasikan untuk mendukung kegiatan rehabilitasi. Maka dari itu, tujuan dari pengembangan game adalah menghadirkan rehabilitasi yang menarik dan nyaman. Sasaran pengguna pada penelitian ini yaitu pasien cedera bahu yang sedang menjalani rehabiliasi terjadwal.

Dari sekian banyak gerakan rehabilitasi, Shoulder Active Abduction merupakan gerakan yang sederhana dan lebih banyak mencakup gerakan rehabilitasi cedera bahu serta mudah untuk diterapkan dalam game simulasi sesuai prosedur rehabilitasi. Kinect dapat melacak gerakan tubuh dengan cukup akurat [6]. Tujuan simulasi pada video game dalam kegiatan rehab medik adalah untuk merangsang mobilitas atau gerakan pada tubuh lebih aktif lagi karena perhatian pasien yang fokus pada alur game [7]. Tak hanya itu, rehabilitasi pun dapat dilakukan secara mandiri [8], menghemat biaya, dan dapat mengetahui evaluasi pemulihan cedera secara langsung [9]. Penelitian terdahulu yang mengimplementasikan video game sebagai pendukung rehabilitasi membuktikan rehabilitasi terkesan menarik dan memotivasi kebugaran fisik [10]. Kinect adalah sensor citra 3D yang mampu mengenali 20 sendi tubuh manusia [11] yang disebut matchstick skeleton dengan kemampuan pelacakan 30 frame per detik [12]. Gerakan lengan yang direkam menggunakan sensor Kinect dapat menganalisis sendi dalam ruang 3D [13], diharapkan dapat membantu dokter spesialis rehab medik maupun ahli fisioterapi untuk mengevaluasi pemulihan cedera [14].

Perkembangan teknologi saat ini membuat teknologi machine learning dimana mesin seakanakan mampu mempelajari dan mengenali pola pada suatu data untuk memecahkan suatu permasalahan. Jaringan saraf tiruan merupakan pemrosesan suatu informasi yang mendasari jaringan sel saraf biologis [15], dapat diterapkan dalam game untuk tujuan tertentu [16]. Backpropagation termasuk ke dalam kelompok jaringan saraf tiruan dengan pelatihan yang terawasi menggunakan pola penyesuaian bobot untuk mencapai nilai kesalahan yang minimum antar keluaran hasil prediksi dengan keluaran yang nyata. Hal tersebut terbukti bahwa keunggulan Backpropagation karena terdapat lapisan tersembunyi yang mampu mengenali pola nonlinier apapun dengan akurasi besar, kecepatan konvergensi yang tinggi [17] atau kecepatan dalam pelatihan [18], meminimalkan kesalahan [19], dibandingkan dengan metode regresi. Maka dari itu mengenali pola gerakan Shoulder Active Abduction dapat dilakukan saat latihan terapi terhadap pasien cedera bahu menggunakan Backpropagation [20]. Sehingga tujuan dari mengenali pola tersebut dapat diterapkan untuk sebuah sistem dalam memprediksi tingkat pemulihan cedera pasien.

Penelitian ini berfokus pada pembuatan sistem yang dikemas dalam game simulasi, yang bertujuan untuk memprediksi tingkat pemulihan cedera bahu dengan pembelajaran mesin sebagai bahan evaluasi saat menjalani latihan terapi. Selain itu, tujuan simulasi yang divisualisasikan ke dalam game interaktif agar dapat mengalihkan perhatian pasien dari lingkungan rehabilitasi untuk lebih memotivasi pasien mengikuti proses rehabilitasi. Game dirancang sederhana yang dapat diikuti oleh pasien sesuai dengan petunjuk dan prosedur rehabilitasi. Gerakan lengan pasien yang ditinjau adalah Shoulder Active Abduction berupa mengangkat lengan menjauhi garis tengah dari bidang frontal pada tubuh. Gerakan tersebut direkam menggunakan sensor Kinect dengan ruang 3D yang direpresentasikan menjadi nilai 
sudut lengan dengan rentang $0^{\circ}-180^{\circ}$. Nilai-nilai sudut tersebut selanjutnya digunakan untuk memprediksi tingkat pemulihan cedera bahu menggunakan metode Backpropagation.

\section{A. Sensor Kinect}

Kinect dikembangkan oleh Rare, sebuah perusahaan game dibawah Microsoft Game Studios milik Microsoft. Kinect yang digunakan untuk video game personal computer dengan sistem operasi Windows mampu memberikan perintah atau bermain game lewat gerakan tangan dan suara. Menggunakan proyektor infrared dan camera dan sebuah microchip untuk mendeteksi gerakan obyek dalam tiga dimensi, maka dalam mengontrol game cukup dengan melakukan gerakan-gerakan yang biasa dilakukan. Software Kinect secara otomatis mampu melakukan kalibrasi pada sensor berdasarkan gameplay dan lingkungan fisik pemain. Perangkat Kinect dapat dilihat pada Gambar 1.

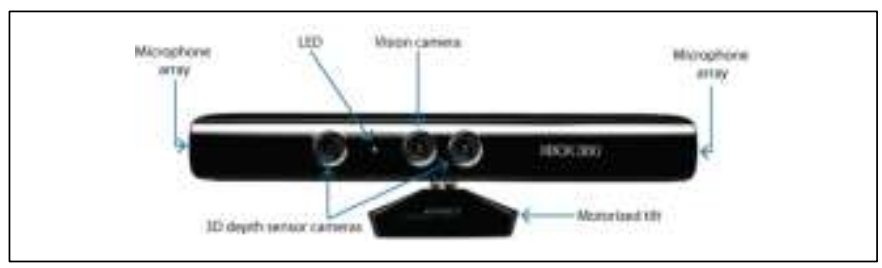

Gambar 1. Perangkat Microsoft Kinect Xbox 360

\section{II.METODE}

Penelitian ini dilakukan berdasarkan rancangan diagram sistem prediksi pemulihan cedera bahu. Rancangan diagram sistem prediksi pemulihan cedera bahu dapat dilihat pada Gambar 2.

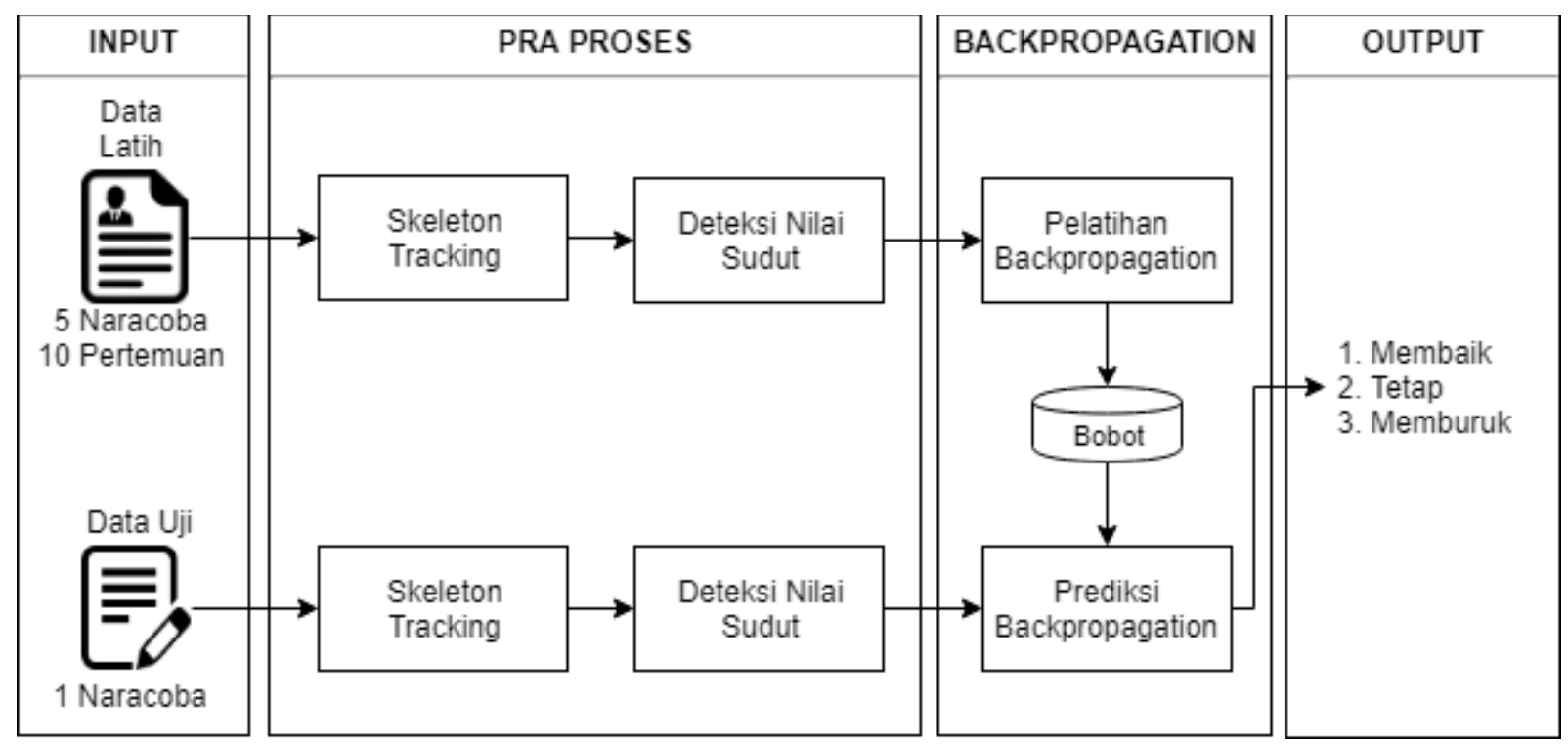

Gambar 2. Perancangan prediksi pemulihan cedera bahu

\section{A. Akuisisi Data}

Pada penelitian ini data yang digunakan adalah data hasil perekaman gerakan Shoulder Active Abduction pasien cedera bahu. Pengambilan data sudah mendapatkan izin penelitian kode etik terlebih dahulu. Perekaman gerakan lengan menggunakan sensor Kinect terhadap lima pasien cedera bahu yang sedang menjalani rehabilitasi, dengan 10 kali pertemuan. 
Pengambilan data diambil pada saat pasien melakukan rehabilitasi cedera bahu di klinik rehab medik RSUP Dr. Hasan Sadikin yang sudah terjadwal. Perekaman dilakukan dalam posisi berdiri menghadap layar monitor dan sensor Kinect dengan jarak 1,5 meter yang kemudian melakukan 10 kali gerakan Shoulder Active Abduction semampunya dan tidak terpaku oleh waktu. Posisi Kinect diletakan lurus sejajar dengan bahu agar dapat menganalisis nilai sudut dengan baik. Data perekaman berupa variasi nilai sudut yang berhasil direkam dan disimpan dalam bentuk csv seperti pada Tabel 1.

TABEL 1. Dataset Nilai Sudut Lengan

\begin{tabular}{|c|c|c|c|c|c|c|c|c|c|}
\hline \multirow{3}{*}{ Pasien ke } & \multicolumn{3}{|c|}{ Sesi ke 1} & \multicolumn{3}{|c|}{ Sesi ke ... } & \multicolumn{3}{|c|}{ Sesi ke 10} \\
\hline & & & & & erah & & & & \\
\hline & 1 & $\ldots$ & 10 & 1 & $\ldots$ & 10 & 1 & $\ldots$ & 10 \\
\hline 1 & 95 & $\ldots$ & 115 & 98 & $\ldots$ & 113 & 106 & $\ldots$ & 129 \\
\hline 2 & 87 & $\ldots$ & 98 & 96 & $\ldots$ & 103 & 92 & $\ldots$ & 117 \\
\hline 3 & 94 & $\ldots$ & 85 & 89 & $\ldots$ & 92 & 90 & $\ldots$ & 94 \\
\hline 4 & 104 & $\ldots$ & 102 & 109 & $\ldots$ & 112 & 101 & $\ldots$ & 110 \\
\hline 5 & 120 & $\ldots$ & 128 & 115 & $\ldots$ & 121 & 119 & & 133 \\
\hline
\end{tabular}

\section{B. Pra Proses}

Teknologi sensor Kinect dapat menangkap 20 titik kunci atau dikenal sebagai matchstick skeleton pada tubuh manusia. Pada penelitian ini titik yang dibutuhkan hanya 3 dari 20 titik kunci berupa shoulder, elbow, dan wrist. Kinect menyediakan ruang 3D yang menghasilkan nilai koordinat $x, y$ dan $z$. Nilai koordinat tersebut lalu diterjemahkan ke dalam nilai sudut menggunakan Persamaan 1. Gerakan pertama digunakan untuk memperoleh input awal yang diambil dari nilai gerakan mengangkat lengan paling tinggi. Gerakan selanjutnya digunakan untuk memperoleh suatu nilai yang akan dibandingkan dengan gerakan sebelumnya sehingga mendapatkan nilai selisih. Nilai selisih dari setiap gerakan merupakan nilai yang akan dijadikan vektor input untuk diprediksi menggunakan Backpropagation.

\section{1) Perolehan Nilai Sudut}

Nilai sudut diperoleh dari perekaman mengangkat lengan menjauhi garis tengah terhadap bidang frontal pada tubuh semampunya. Gerakan tersebut dilakukan secara berulang sebanyak 10 kali yang menghasilkan nilai sudut bervariasi dengan rentang $0^{\circ}-180^{\circ}$. Nilai sudut diperoleh dari 3 titik sendi yang direkam oleh sensor Kinect yaitu shoulder, elbow dan wristmenggunakan Persamaan 1.

$$
\begin{aligned}
& b a=(\text { shoulder } X-\text { elbow } X, \text { shoulder } Y-\text { elbow } Y, \text { shoulder } Z-\text { elbowZ }) \\
& b c=(\text { wrist } X-\text { elbow } X, \text { wrist } Y-\text { elbow } Y, \text { wrist } Z-\text { elbow }) \\
& b a A b s=\sqrt{b a X^{2}+b a Y^{2}+b a Z^{2}} \\
& b c A b s=\sqrt{b c X^{2}+b c Y^{2}+b c Z^{2}} \\
& \text { Angle }=\frac{360}{\pi \times 2} \times \operatorname{ArcCos}\left(\frac{(b a X \times b c X)+(b a Y \times b c Y)+(b a Z \times b c Z)}{(b a A b s \times b c A b s)}\right)
\end{aligned}
$$

Pengambilan titik sendi untuk menganalisis nilai sudut dari gerakan Shoulder Active Abduction yang direkam menggunakan sensor Kinect dapat dilihat pada Gambar 3. 


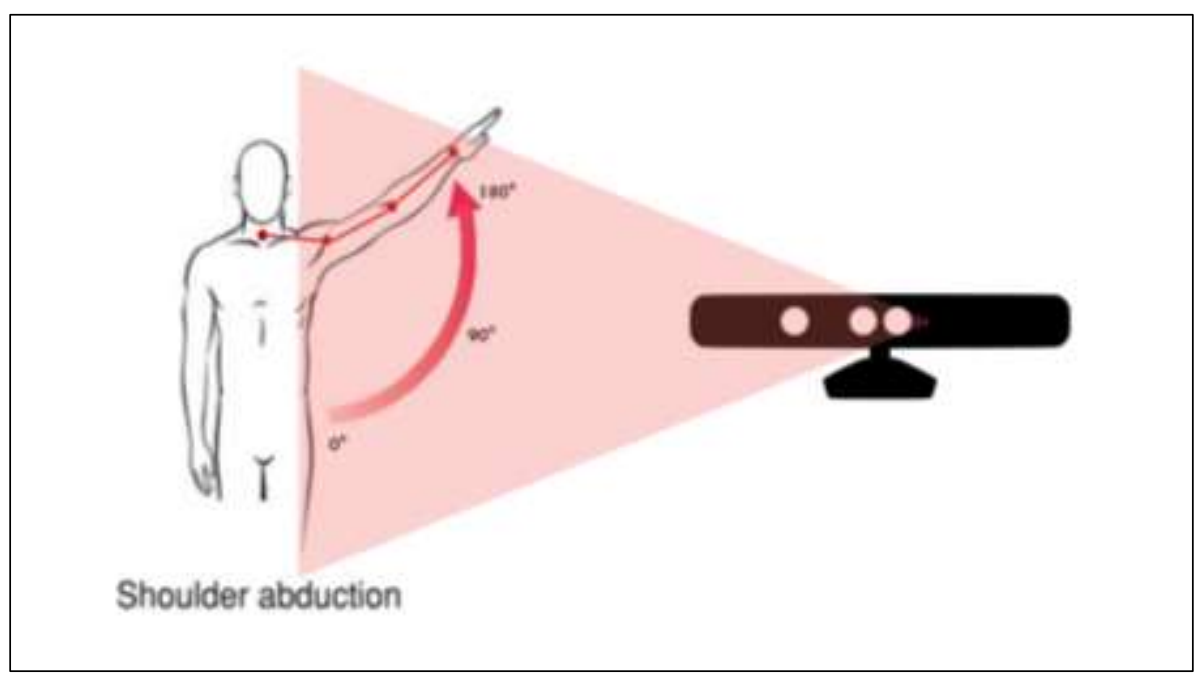

\section{Gambar 3. Representasi gerakan shoulder active abduction}

\section{Backpropagation}

Backrpopagation adalah algoritma pembelajaran dengan metode supervised learning yang memiliki banyak lapisan untuk mengubah bobot yang terhubung dengan neuron-neuron lapisan tersembunyi. Backpropagation memiliki kemampuan mengenali pola non-linier, meminimalkan kesalahan, dan pelatihan yang cepat sehingga banyak digunakan untuk kasus prediksi [17]. Data latih yang diperoleh dari lima naracoba pasien cedera bahu yang sudah dilakukan pra proses terlebih dahulu, kemudian diproses untuk pelatihan menggunakan algoritma Backpropagation.

Backpropagation menggunakan arsitektur Multilayer Perceptron untuk mengubah bobot yang terhubung dengan neuron-neuron yang terdapat pada hidden layer dan fungsi aktivasi sigmoid biner pada output layer. Untuk menentukan hidden layer dapat menggunakan Persamaan 2 dan Persamaan 3 dengan fungsi aktivasi sigmoid biner.

$$
p=\sqrt{ }(m \times n)
$$

dimana :

$m=$ jumlah neuron input

$n=$ jumlah neuron output

$$
f^{\prime}(x)=f(x)(1-f(x))
$$

dimana :

$e=$ nilai eksponen

$x=$ input data yang diaktivasi

Dalam pelatihan Backpropagation memiliki tiga tahapan yang akan dilakukan untuk proses identifikasi yaitu feed forward, back propagation dan modifikasi bobot. Berikut adalah penjelasan dari ketiga fase pada Backpropagation.

\section{1) Tahap Feed Forward}

Feed Forward atau fase maju yaitu setiap neuron input $x_{i}$ akan mengirimkan sinyal masukan pada hidden layer. Masing-masing neuron pada hidden layer dikalikan dengan 
bobot dan dijumlahkan dengan bias. Perhitungannya dilakukan menggunakan Persamaan 4.

$$
\text { Z_net } j=v j 0+\Sigma n X i V k j
$$

dimana :

i $\quad=$ indeks neuron input

$j \quad=$ indeks neuron hidden

vjo = bobot bias dari input layer ke hidden layer

$n \quad=$ jumlah neuron pada input layer

$x i=$ data nilai masukkan yang ke- $i$

$v k j=$ bobot dari input layer ke hidden layer

Selanjutnya melakukan perhitungan pada masing-masing neuron outputyang dikalikan dengan bobot dan dijumlahkan dengan bias menggunakan Persamaan 5.

$$
y \_n e t k=w k 0+\Sigma p z j y k j
$$

dimana:

$j \quad=$ indeks neuron hidden layer

$p \quad=$ jumlah neuron pada hidden layer

$k \quad=$ indeks neuron output

$w k 0=$ bobot bias dari hidden layer ke output layer

zj $\quad=$ nilai hasil aktivasi dari hidden layer

ykj = bobot dari hidden layer ke output layer

2) Tahap Backpropagation

Backpropagation atau fase mundur merupakan tahap masing-masing neuron outputmenerima pola target yang telah dicapai berdasarkan pola masukan saat pelatihan. Dalam perhitungan untuk perubahan bias menggunakan Persamaan 6.

$$
\Delta w k 0=a \times \delta k
$$

dimana:

$a \quad=$ nilai learning rate

$\delta k=$ komponen kesalahan pada output layer

3) Tahap Modifikasi Bobot

Pada tahp ini semua bobot dimodifikasi secara bersamaan. Hal tersebut dilakukan untuk meminimalkan kesalahan yang terjadi pada proses feed forward dan backpropagation. Melakukan perhitungan kesalahan pada setiap hidden layer, pembaharuan bias dan bobot dari masing-masing neuron output sehingga menghasilkan bobot dan bias baru menggunakan Persamaan 7. Perhitungan pada setiap neuron hidden dimulai dari unit ke-1 sampai unit ke- $p$ menggunakan Persamaan 7.

$w k j=w k j($ lama $)+\Delta w k j$

$V j i=v j i($ lama $)+\Delta v j i$ 
dimana :

$w k j$ (lama) $=$ bobot neuron hidden ke output yang lama

$\Delta w k j=$ koreksi bobot $\mathrm{W}$

vji (lama) = bobot neuron input ke hidden yang lama

$\Delta v j i \quad=$ koreksi bobot $\mathrm{V}$

Arsitektur Multilayer Perceptron yang digunakan pada penelitian ini terdiri dari input layer, hidden layer, dan output layer yang ditunjukan pada Gambar 3. Proses pembelajaran dimulai dengan komputasi setiap neuron input layer sebanyak 10 neuron terhadap setiap neuron yang ada pada hidden layer sebanyak enam neuron, lalu diteruskan hingga setiap neuron dalam output layer sebanyak tiga neuron. Neuron-neuron pada hidden layer diperoleh dengan menggunakan Persamaan 2. Untuk bobot awal didapatkan dari nilai secara acak dengan rentang -1 sampai dengan 1.

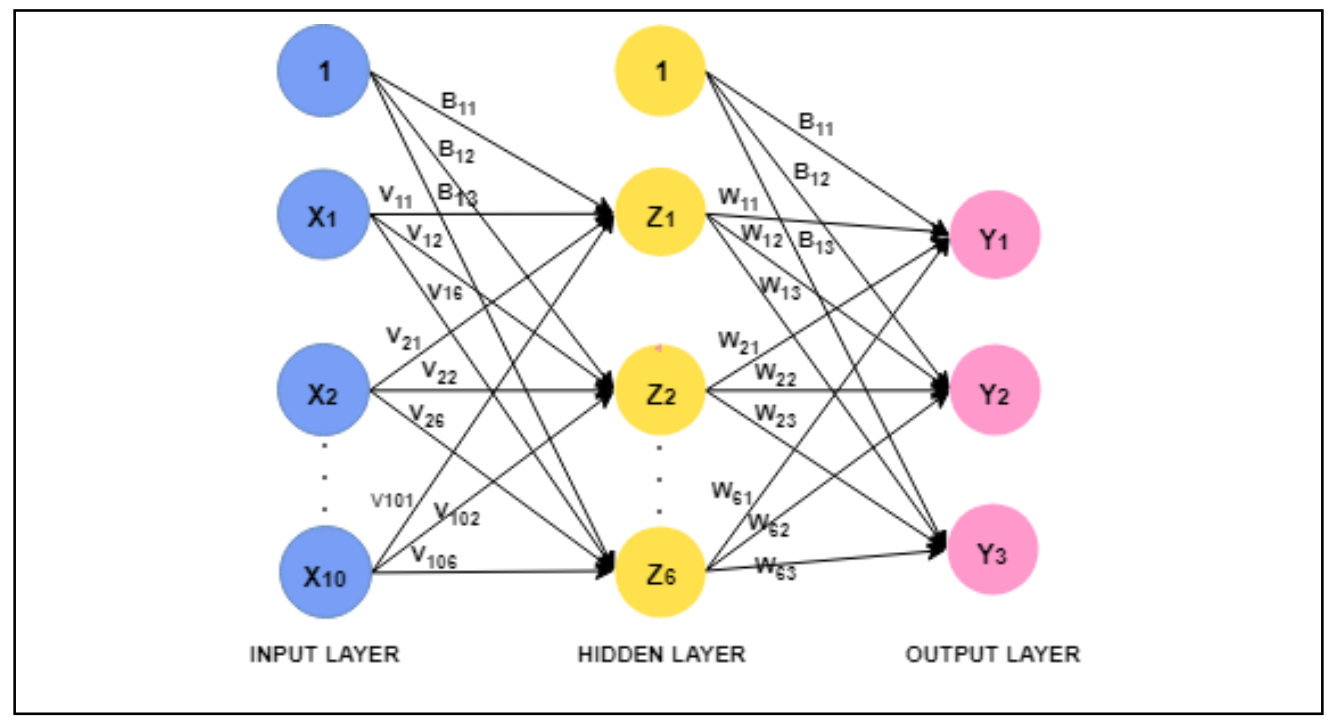

Gambar 4. Arsitektur multilayer perceptron

Pelatihan dilakukan hingga MSE hasil tidak melebihi nilai target error. Namun penghentian iterasi akan dilakukan walaupun MSE hasil belum memenuhi syarat apabila iterasi atau epoch lebih besar dari jumlah epoch yang ditetapkan. Bobot terakhir dari pelatihan akan disimpan dan akan digunakan pada proses identifikasi. Identifikasi hanya dilakukan sampai pada fase pertama yaitu feed forward karena tidak adanya perbaikan bobot.

\section{HASIL DAN DISKUSI}

Pada tahap ini pasien diarahkan untuk memainkan game Throw the Pokeball yang merupakan simulasi dari gerakan Shoulder Active Abduction. Pasien dalam keadaan berdiri tepat menghadap sensor Kinect dan layar atau monitor berisi game. Gerakan dimulai dari keadaan siku lurus, kemudian mengangkat lengan perlahan yang merepresentasikan bola sedang ditarik, kemudian lengan diturunkan hingga kembali ke titik awal maka bola pun akan terlempar menuju target atau musuh. Semakin tinggi lengan diangkat maka bola akan terlempar semakin kencang dan memperoleh skor sesuai dengan tarikan bola yang dilempar. Gerakan lengan pasien untuk mengontrol bola tetap berupa gerakan mengangkat lengan menjauhi garis tengah dari bidang frontal pada tubuh. Gerakan dilakukan sebanyak 10 kali untuk menghasilkan nilai sudut maksimum yang bervariasi. Untuk gameplay pada penelitian ini dapat dilihat pada Gambar 5. 


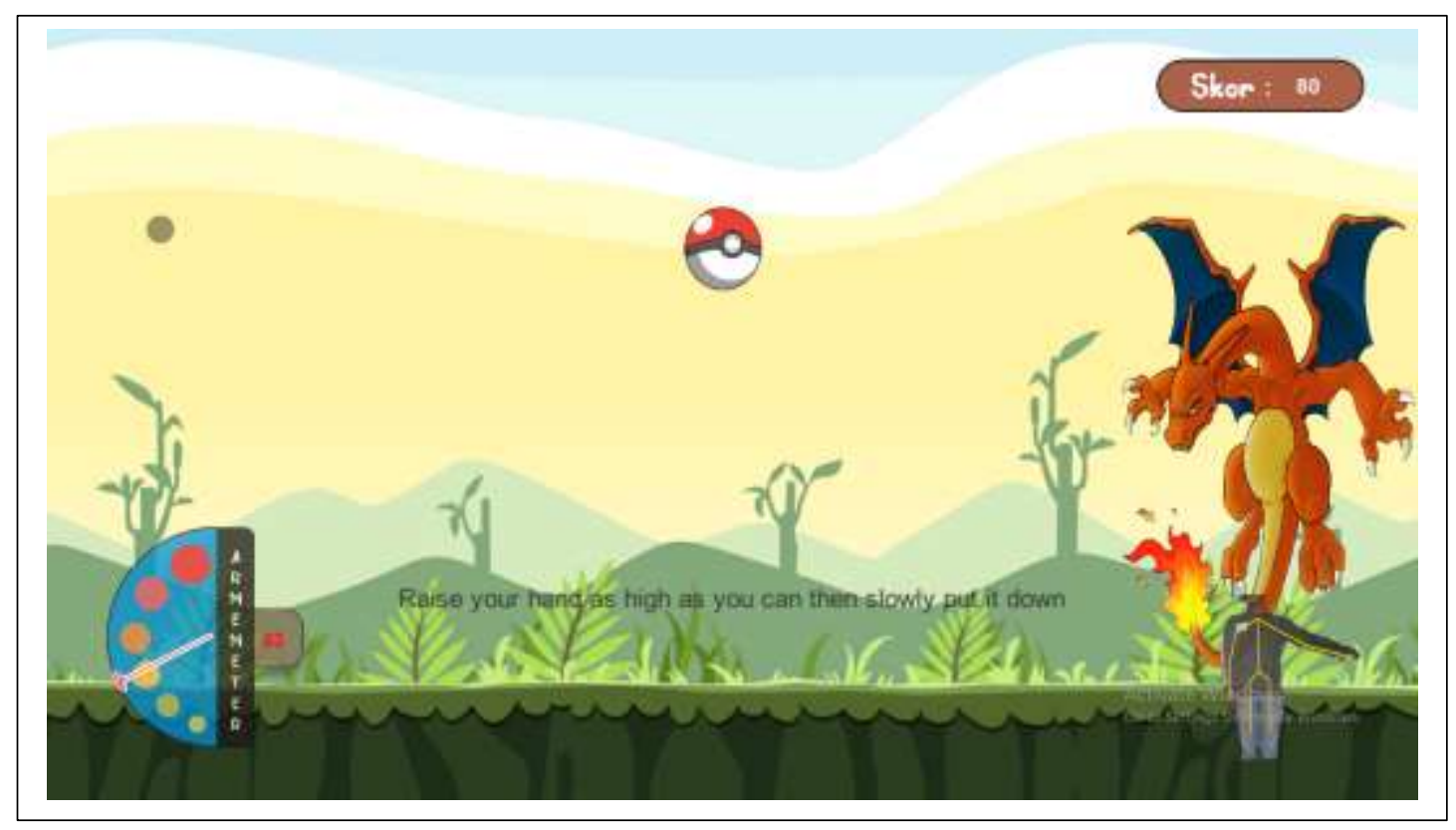

Gambar 5. Gameplay Throw the Pokeball

Setelah melakukan 10 kali gerakan mengangkat lengan maka akan tampil hasil prediksi yang merupakan evaluasi pemulihan cedera bahu berupa presentase dari setiap status pemulihan cedera yaitu meningkat, tetap dan menurun secara real time. Berikut nilai target keluaran dari masing-masing kelas, dapat dilihat pada Tabel 2.

TABEL 2. Target Keluaran Setiap Kelas

\begin{tabular}{|l|l|}
\hline \multicolumn{1}{|c|}{ Kelas } & \multicolumn{1}{c|}{ Target Keluaran } \\
\hline Menurun & 001 \\
\hline Tetap & 010 \\
\hline Membaik & 100 \\
\hline
\end{tabular}

Prediksi pemulihan cedera bahu pada game ini didapatkan dari hasil pembelajaran mesin menggunakan Backrpopagation, dimana data pelatihan diperoleh dari hasil perkeman offline terhadap lima pasien cedera bahu frozen shoulder yang sedang menjalani kegiatan rehabilitasi terjadwal. Data yang digunakan untuk penelitian ini yaitu 50 set data, data tersebut dibagi menjadi dua yaitu $80 \%$ (40 set data) untuk data latih dan 20\% (10 set data) untuk data uji. Parameter pelatihan yang digunakan, yaitu 200 epoch dengan learning rate 0,01 . Grafik untuk nilai akurasi hasil pelatihan dapat dilihat pada Gambar 6 dan grafik untuk nilai loss dapat dilihat pada Gambar 7.

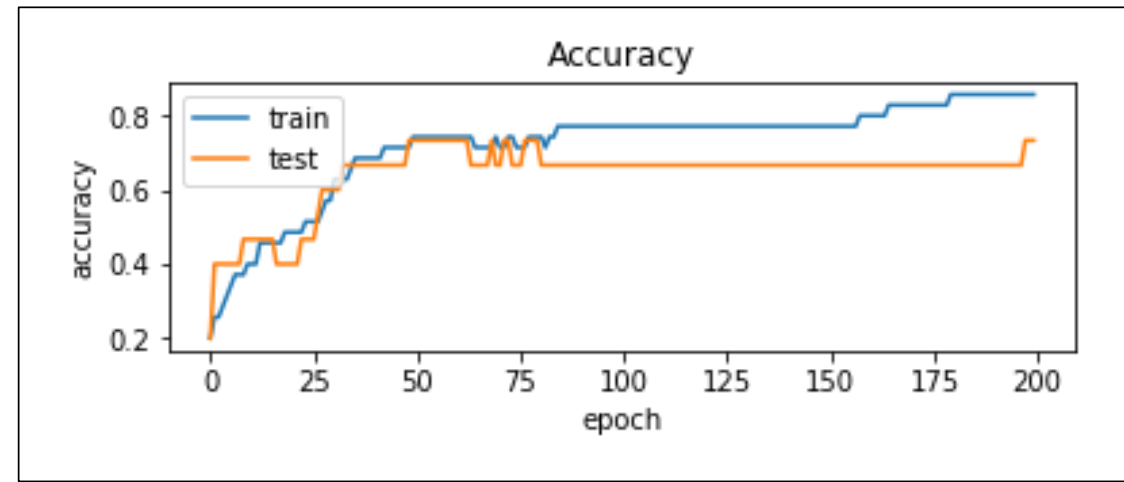

Gambar 6. Model akurasi data latih dan data uji dengan 200 epoch

Paper ini berasal dari Konferensi Nasional SNIA 2019 pada 26 September

JUMANJI -24

2019 bertempat di Hotel Grand Aquila Bandung 


\section{Game Simulasi Gerakan Pasien Cedera Bahu Menggunakan Jaringan Saraf Tiruan Backpropagation}

Berdasarkan grafik pada Gambar 6 dapat dilihat hasil akurasi dari pelatihan menggunakan Backpropagation dengan enam layer hidden neuron dan learning rate 0,01 yang dilakukan pada data latih memperoleh hasil akurasi $82 \%$ dan data uji sebesar $66,7 \%$.

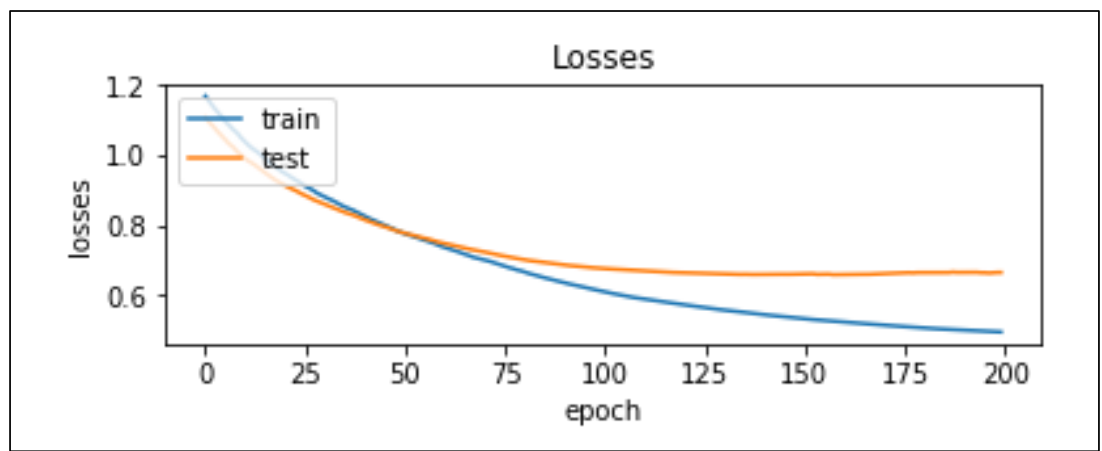

\section{Gambar 7. Nilai loss dengan Mean Square Error}

Dilihat dari hasil grafik pada Gambar 7 nilai Loss yang dihasilkan menggunakan MSE (Mean Square Error) terjadi konvergensi pada Epoch ke-175 menuju Epoch ke-200, yang menandakan nilai error untuk data latih yang kecil pada pelatihan yaitu 0,01 . Sehingga menghasilkan akurasi yang baik pada data latih maupun data uji.

\section{KESIMPULAN}

Penelitian ini telah membangun sebuah game simulasi yang mampu mengevaluasi tingkat pemulihan cedera yang diterjemahkan dalam nilai sudut pada sendi terhadap pasien cedera bahu. Selanjutnya game diuji kepada pasien yang sedang menjalani rehabilitasi cedera bahu jenis Frozen Shoulder yang sudah terjadwal. Pada sistem, tahap pertama yang dilakukan adalah tahap praproses terlebih dahulu untuk mengubah nilai koordinat $\mathrm{x}, \mathrm{y}$ dan $\mathrm{z}$ dari sensor Kinect direpresentasikan ke dalam nilai sudut dari $0^{\circ}-180^{\circ}$. Setelah memperoleh nilai-nilai sudut yang diperlukan lalu Backpropagation digunakan untuk pelatihan dan pengujian yang digunakan sebagai prediksi berupa evaluasi pemulihan cedera pada game Throw the Pokeball. Backpropagation merupakan metode yang sederhana dan mampu menghasilkan nilai akurasi yang baik. Dalam kasus ini, pelatihan menggunakan Backpropagation dilakukan terhadap enam neuron hidden, dengan learning rate 0,01 memperoleh akurasi data latih sebesar $82 \%$ dan akurasi data uji sebesar $66,7 \%$. Jika terdapat nilai akurasi yang kecil, dikarenakan data latih yang kurang bervariasi. Hal tersebut berpengaruh pada pengujian sistem.

\section{UCAPAN TERIMAKASIH}

Terimakasih kepada RSUP Dr. Hasan Sadikin Bandung, khususnya unit Klinik Rehabilitasi Medik yang telah memberikan izin untuk kepentingan pengambilan data dalam penelitian ini.

\section{DAFTAR PUSTAKA}

[1] A. Suharti, R. Sunandi, and F. Abdullah, "Penatalaksanaan Fisioterapi pada Frozen Shoulder Sinistra Terkait Hiperintensitas Labrum Posterior Superior di Rumah Sakit Pusat Angkatan Darat Gatot Soebroto," Jurnal Vokasi Indonesia, vol. 1, no. 80, pp. 51-65, 2018.

[2] S. Bhardwaj, A. A. Khan, and M. Muzammil, "Electromyography in Physical Rehabilitation: A Review," National Conference on Mechanical Engineering - Ideas, Innovations \& Initiatives, no. April, pp. 64-69, 2016.

[3] B. Cubukcu and U. Yuzgec, "A physiotherapy application with MS kinect for patients with shoulder joint, muscle and tendon damage," Proceedings - 9th International Conference 
on Computational Intelligence and Communication Networks, CICN 2017, vol. 2018Janua, pp. 225-228, 2018.

[4] M. N. A. Van Der Kuil, I. J. M. Van Der Ham, and J. M. A. Visser-Meily, "Game technology in cognitive rehabilitation of spatial navigation impairment," International Conference on Virtual Rehabilitation, ICVR, vol. 2017-June, pp. 1-2, 2017.

[5] D. Dauria, F. Persia, and B. Siciliano, "Human-Computer Interaction in Healthcare: How to Support Patients during Their Wrist Rehabilitation," Proceedings - 2016 IEEE 10th International Conference on Semantic Computing, ICSC 2016, pp. 325-328, 2016.

[6] A. Mobini, S. Behzadipour, and M. Saadat Foumani, "Accuracy of Kinect's skeleton tracking for upper body rehabilitation applications," Disability and Rehabilitation: Assistive Technology, vol. 9, no. 4, pp. 344-352, 2014.

[7] M. Pedraza-Hueso, S. Martín-Calzón, F. J. Díaz-Pernas, and M. Martínez-Zarzuela, "Rehabilitation Using Kinect-based Games and Virtual Reality," Procedia Computer Science, vol. 75, no. Vare, pp. 161-168, 2015.

[8] K. C. Yang, C. H. Huang, and C. F. Le, "Applying microsoft kinect for windows to develop a Stroke Rehabilitation System," IEEE International Conference on Industrial Engineering and Engineering Management, vol. 2016-Decem, no. 2, pp. 1923-1927, 2016.

[9] K. Ongvisatepaiboon, J. H. Chan, and V. Vanijja, "Smartphone-based tele-rehabilitation system for frozen shoulder using a machine learning approach," Proceedings - 2015 IEEE Symposium Series on Computational Intelligence, SSCI 2015, pp. 811-815, 2015.

[10] B. Shroeder et al., "Rapid recovery: a kayaking-based exergame for shoulder rehabilitation and physical fitness," IEEE Games Media Entertainment, pp. 1-4, 2015.

[11] N. Gal, D. Andrei, D. I. Nemeş, E. Nədəşan, and V. Stoicu-Tivadar, "A Kinect based intelligent e-rehabilitation system in physical therapy," Studies in Health Technology and Informatics, vol. 210, pp. 489-493, 2015.

[12] M. A. Rahman, M. Ahmed, A. Qamar, D. Hossain, and S. Basalamah, "Modeling therapy rehabilitation sessions using non-invasive serious games," IEEE MeMeA 2014 - IEEE International Symposium on Medical Measurements and Applications, Proceedings, pp. $1-4,2014$.

[13] O. Postolache, F. Cary, P. S. Girao, and N. Duarte, "Physiotherapy assessment based on Kinect and mobile APPs," IISA 2015 - 6th International Conference on Information, Intelligence, Systems and Applications, 2016.

[14] Y. C. Chen, H. J. Lee, and K. H. Lin, "Measurement of body joint angles for physical therapy based on mean shift tracking using two low cost Kinect images," Engineering in Medicine and Biology Society (EMBC), pp. 703-706, 2015.

[15] A. Hassan Mansour, G. Z. Alabdeen Salh, and H. H. Zeen Alabdeen, "Voice recognition Using back propagation algorithm in neural networks," International Journal of Computer Trends and Technology, vol. 23, no. 3, pp. 132-139, 2015.

[16] E. Tanuar, B. S. Abbas, A. Trisetyarso, C. H. Kang, F. L. Gaol, and W. Suparta, "Back propagation neural network experiment on team matchmaking MOBA game," 2018 International Conference on Information and Communications Technology, ICOIACT 2018, vol. 2018-Janua, pp. 240-243, 2018.

[17] A. Sharaff and S. R. Roy, "Comparative Analysis of Temperature Prediction Using Regression Methods and Back Propagation Neural Network," Proceedings of the 2nd International Conference on Trends in Electronics and Informatics, ICOEI 2018, no. Icoei, pp. 739-742, 2018.

[18] Z. G. Che, T. A. Chiang, and Z. H. Che, "Feed-forward neural networks training: A comparison between genetic algorithm and back-propagation learning algorithm," 
Game Simulasi Gerakan Pasien Cedera Bahu Menggunakan Jaringan Saraf Tiruan Backpropagation

International Journal of Innovative Computing, Information and Control, vol. 7, no. 10, pp. 5839-5850, 2011.

[19] S. Amalia, "Pengenalan Digit 0 Sampai Digit 9 Menggunakan Ekstraksi Ciri MFCC dan Jaringan Syaraf Tiruan Backpropagation," Jurnal Teknik Elektro ITP, vol. 6, no. 1, pp. 114, 2011.

[20] T. W. Cenggoro, A. H. Kridalaksana, E. Arriyanti, and M. I. Ukkas, "Recognition of a human behavior pattern in paper rock scissor game using backpropagation artificial neural network method," 2014 2nd International Conference on Information and Communication Technology, ICoICT 2014, pp. 238-243, 2014. 